\title{
Functional properties of protein isolates from camelina (Camelina sativa (L.) Crantz) and flixweed (sophia, Descurainis sophia L.) seed meals
}

Na Thi Ty Ngo and Fereidoon Shahidi

\begin{abstract}
Camelina and flixweed (sophia) seed protein isolates were prepared using both the conventional extraction and ultrasonic-assisted extraction methods at $40 \mathrm{kHz}$ for $20 \mathrm{~min}$, and their functional properties investigated. SDS-PAGE showed that both ultrasound-assisted and conventional extractions resulted in a similar protein profile of the extract. The application of ultrasound significantly improved protein extraction/content and functional properties (water holding capacity, oil absorption capacity, emulsifying foaming properties, and protein solubility) of camelina protein isolate and sophia protein isolate. The water-holding and oil absorption capacities of sophia protein isolate were markedly higher than those of camelina protein isolate. These results suggest that camelina protein isolate and sophia protein isolate may serve as natural functional ingredients in the food industry.
\end{abstract}

Keywords: Camelina seed, Sophia seed, Protein isolate, Functional properties, Ultrasound treatment

* Correspondence: fshahidi@mun.ca

Department of Biochemistry, Memorial University of Newfoundland, A1B 3X9 St. John's, NL, Canada

(c) The Author(s). 2021 Open Access This article is licensed under a Creative Commons Attribution 4.0 International License, which permits use, sharing, adaptation, distribution and reproduction in any medium or format, as long as you give appropriate credit to the original author(s) and the source, provide a link to the Creative Commons licence, and indicate if changes were made. The images or other third party material in this article are included in the article's Creative Commons licence, unless indicated otherwise in a credit line to the material. If material is not included in the article's Creative Commons licence and your intended use is not permitted by statutory regulation or exceeds the permitted use, you will need to obtain permission directly from the copyright holder. To view a copy of this licence, visit http://creativecommons.org/licenses/by/4.0/. 


\section{Graphical Abstract}

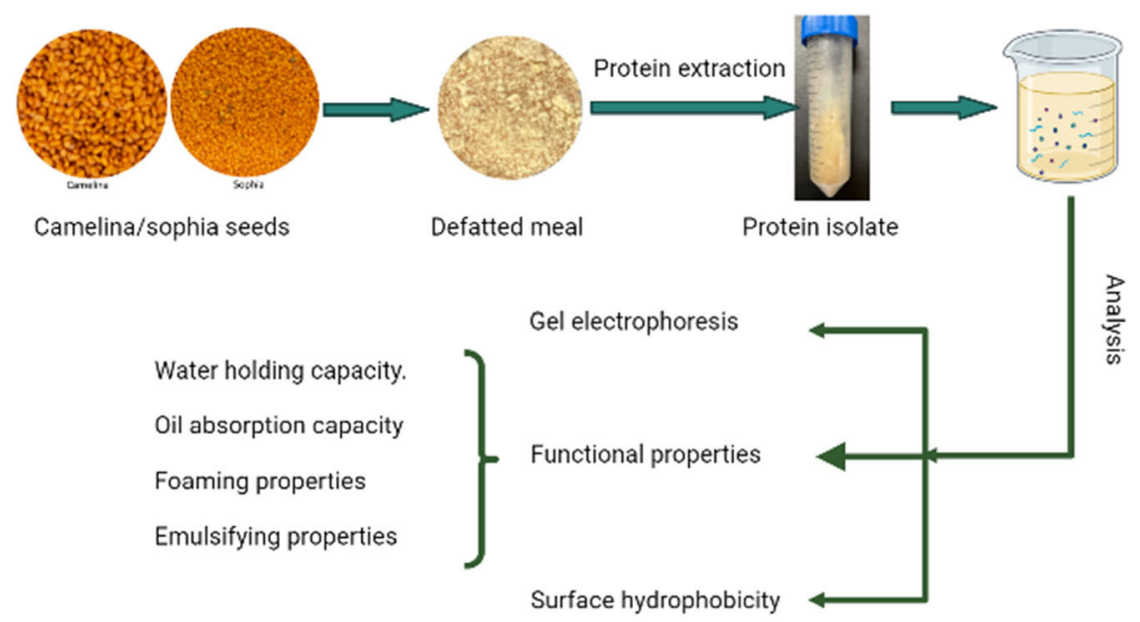

Created in BioRender.com bio

\section{Introduction}

Proteins play a crucial role in both biological systems and human nutrition. Compared with animal-based proteins, plant-derived proteins are currently receiving much interest as they are sustainable and readily available with much economic attraction (Deng et al. 2019; $\mathrm{Du}$ et al. 2018). Hence, diversified sources of plant proteins increasingly address the worldwide requirement as an ingredient in the food industry.

Over the last few years, attraction to proteins from food processing by-products has intensified. Protein isolates play an integral part in the development of food with desirable functional properties (Yagoub et al. 2017). Many efforts have been made to develop efficient methods to produce a high-quality protein with good utilization value. Camelina (Camelina sativa (L.) Crantz) and flixweed, also known as sophia (Descurainis sophia L.) belong to the family Brassicaceae and may serve as novel sources of plant protein. In addition, camelina is a new potential oilseed source in North America, particularly for use in aquaculture feed. Camelina meal is the by-product of the oil extraction process from Camelina seeds. Defatted camelina meal contains approximately $45 \%$ protein, residual crude fat $4.9 \%$, up to $15 \%$ insoluble fiber, up to $10 \%$ carbohydrates, $3 \%$ minerals, and approximately $4 \%$ phytochemicals, dominated by phenolics and other compounds such as vitamins (Das et al. 2014; Rahman, Costa de Camargo, \& Shahidi, 2018). Furthermore, the nutritional quality of camelina protein is similar to that of canola protein and competes with soy protein for some applications targeting the use of plant proteins ( $\mathrm{Li}$ et al. 2015). However, there are very few studies on extracted proteins and hydrolysates from camelina (Boyle et al. 2018; Li et al. 2014).

Sophia seeds have been used as a traditional medicine to relieve cough and chest discomfort, prevent asthma, and treat cancer. It can be found throughout Canada as well as in Iran and China (HadiNezhad et al. 2015). The seed contains $28 \%$ protein, $33 \%$ oil, and $4 \%$ ash (Rahman et al. 2018). Their amino acids include aspartic acid, threonine, serine, glutamic acid, proline, glycine, alanine, valine, isoleucine, leucine, tyrosine, phenylalanine, histidine, lysine, and arginine (Mohamed and Mahrous 2009). Some studies have investigated the fatty acid profile and phenolic compounds of sophia seeds (Rahman, Ambigaipalan, et al. 2018; Rahman, Costa de Camargo, et al. 2018). However, no research has been carried out to determine proteins in sophia seeds, and to evaluate their functional properties.

For isolating and recovering proteins, alkaline extraction has become the most popular technique for the preparation of proteins because of its simplicity and cost-effectiveness (Pastuszewska et al. 2000; Phongthai et al. 2016). However, this technique has some potential problems, such as the presence of complex protein constituents with diverse isoelectric points and a wide range of molecular weight distribution (Berot et al. 2005). As a result, an efficient extraction technique plays an essential role in extracting proteins. Numerous studies have shown that ultrasonic-assisted extraction (UAE) is one 
of the most successful extraction methods because it provides some potential benefits such as short extraction time, high extraction yield, low level of solvent use, and the improvement in solubility (Yagoub et al. 2017; Zou et al. 2017). Recent studies have also reported the effects of ultrasound on structural and functional properties of sunflower protein isolates (Malik and Saini 2018; Malik et al. 2017), walnuts (Zhu et al. 2018), faba beans (Martinez-Velasco et al. 2018), and canola protein isolates (Flores-Jimenez et al. 2019). Additionally, the sonicated protein extraction increased gelation capacity while decreasing foaming capacity (Ly et al. 2018). This could lead to improved functional and nutritional properties of food proteins developed by using ultrasonic-assisted technology. However, there are no studies on the effects of ultrasound treatment on the quality of camelina protein isolate (CPI) and sophia protein isolate (SPI). Therefore, more research is needed to fill the existing gap about the functional properties of camelina and sophia protein isolates in order to expand their potential use by the food industry. In this study, CPI and SPI were produced by an ultrasonic-assisted extraction method and the results are compared with the commonly used alkaline extraction procedure for comparative purposes.

\section{Materials and methods}

\section{Materials}

Camelina and flixweed, sophia, seeds were used in this study. Camelina seeds were obtained via Professor Parrish, Memorial University from Linnaeus plant sciences INC, Saskatoon, SK, Canada. Sophia seeds were from Daghdagh Abad, near Hamedan city in Iran, and were purchased from the Tavazo store in Toronto, ON, Canada. All chemicals used were obtained from Fisher Scientific Ltd. (Ottawa, ON, Canada) or Sigma-Aldrich Canada Ltd (Oakville, ON, Canada).

\section{Defatting}

Camelina/ sophia seed samples were defatted with hexane at a 1:5 (w/v) ratio for $5 \mathrm{~min}$ in a Waring blender at room temperature. The above procedure was repeated three times, and samples were then air-dried and stored at $-20^{\circ} \mathrm{C}$ before protein isolation.

\section{Preparation of protein isolate}

\section{Protein extraction from defatted samples by $\mathrm{pH}$ solubilization}

Protein isolates were extracted from defatted meals according to Chavan, McKenzie, and Shahidi (2001) with some modification. The defatted samples were suspended in distilled water (DW) $(3.0 \%, \mathrm{w} / \mathrm{v})$. The mixture was stirred with a magnetic stirrer for $30 \mathrm{~min}$ and the $\mathrm{pH}$ was then adjusted to12 by the addition of a known amount of $2 \mathrm{M} \mathrm{NaOH}$ and stirring for another $60 \mathrm{~min}$ at room temperature. Under similar conditions, the residues were re-extracted two more times with distilled water (DW). The supernatants were combined, and the $\mathrm{pH}$ was adjusted to 4.5 with the addition of $2 \mathrm{M} \mathrm{HCl}$ and then centrifuged at $10,000 \mathrm{x} \mathrm{g}$ for $30 \mathrm{~min}$ at $4{ }^{\circ} \mathrm{C}$ to precipitate the protein. The pellets were collected and then washed twice with DW. The precipitated protein was redispersed in DW and the $\mathrm{pH}$ was adjusted to 7.0 with $1 \mathrm{M} \mathrm{NaOH}$. The extracted proteins were freezedried and stored at $-20{ }^{\circ} \mathrm{C}$ for subsequent analyses.

\section{Ultrasonic-assisted extraction of protein from defatted samples}

For the ultrasound treatment, the defatted samples were mixed in $\mathrm{DW}$, and the $\mathrm{pH}$ of the solution was adjusted to 12 using $2 \mathrm{M} \mathrm{NaOH}$. In the next steps, the suspended sample was placed in an ultrasound bath $(180 \mathrm{~W}$, $40 \mathrm{kHz}, 20 \mathrm{~min}$ ) to extract the proteins. After extraction, the procedure followed was the same as the one under Sec. 2.3.1. The protein content in the supernatant was determined according to the Bradford (1976) method.

\section{Gel electrophoresis}

The protein profile of CPI/SPI was determined by sodium dodecyl sulfate-polyacrylamide gel electrophoresis (SDS-PAGE), according to the method of Laemmli (1970) with $5 \%$ stacking gel and $12 \%$ separating gel. Samples of CPI and SPI were each mixed with buffer (Tris- $\mathrm{HCl}, \mathrm{pH} 8.8$ ). Twenty microliters of the prepared solutions were added to $1 \mathrm{ml}$ buffer (distilled water, $0.5 \mathrm{M}$ Tri-HCl pH 6.8, glycerol, $10 \%$ SDS, $1 \%$ bromophenol blue, and beta-mercaptoethanol) and incubated in boiling water for $5 \mathrm{~min}$ and then centrifuged at $12,000 \mathrm{x} \mathrm{g}$ for $30 \mathrm{~s}$. Ten microliters of samples were applied to the sample wells. The standard protein marker contained (250, 130, 100, 70, 55, 35, 25, 15, and $10 \mathrm{kDa})$ and was used as a molecular weight standard. Electrophoretic migration was monitored at a constant current (100-200 V) for 1.5-2 h. The gel was stained with Coomassie Brilliant Blue R-250 for 60 min. The stained gel was destained by frequently changing the fixing solution until the excess stain disappeared.

\section{Surface hydrophobicity}

Surface hydrophobicity was determined according to the bromophenol blue (BPB) binding method reported by Tontul et al. (2018). BPB has been shown to bind to the same hydrophobic sites on proteins as polarity-sensitive fluorescence probes. Freeze-dried CPI/SPI $(5 \mathrm{mg} / \mathrm{ml}$, w/ v) was dispersed in $20 \mathrm{mM} \mathrm{pH} 7$ phosphate buffer. To the protein solution $(1 \mathrm{ml})$ was added $200 \mu \mathrm{l}$ BPB solution $(1 \mathrm{mg} / \mathrm{mL}$ BPB in distilled water). The control consisted of a $200 \mu \mathrm{l}$ BPB solution and $1 \mathrm{ml}$ phosphate buffer. Test and control samples were agitated for $10 \mathrm{~min}$ 
and then centrifuged at 2,000 $\mathrm{x}$ g for $15 \mathrm{~min}$. The absorbance of the supernatants was read at $595 \mathrm{~nm}$ using a spectrophotometer. Surface hydrophobicity was determined from the bound BPB using the following formula.

$$
\begin{aligned}
\text { Surface hydrophobicity }(\mu \mathrm{g})= & 200 \mu \mathrm{g} \times\left(\mathrm{A}_{\text {control }}\right. \\
& \left.-\mathrm{A}_{\text {sample }}\right) / \mathrm{A}_{\text {control }}
\end{aligned}
$$

Where $\mathrm{A}_{\text {Control }}, \mathrm{A}_{\text {sample }}$ are the absorbance of control and sample, respectively.

\section{Functional properties}

Protein solubility

Protein solubility was measured according to the method described by Ambigaipalan and Shahidi (2015) with some modifications. Freeze-dried CPI/SPI $(1 \mathrm{mg} / \mathrm{ml}$, w/ v) was dispersed in distilled water, and its $\mathrm{pH}$ was adjusted to $2,3,4,5,6,7,9$, and 12 by the addition of $(1 \mathrm{M}$ or $6 \mathrm{M}) \mathrm{HCl}$ or $\mathrm{NaOH}$. The mixture was stirred for $60 \mathrm{~min}$ and then centrifuged at 7,500 x g for $15 \mathrm{~min}$. The protein contents of supernatants were determined using the Bradford (1976) method with bovine serum albumin as a standard, and the total protein content in the sample was determined by solubilizing the sample in $0.5 \mathrm{M} \mathrm{NaOH}$. The solubility of CPI/SPI was expressed as the percentage ratio of the protein content of supernatant to the total protein content using the following equation:

Solubility $(\%)=($ protein content in supernatant $)$ crlow

\section{Water holding capacity (WHC)}

The determination of water holding capacity was carried out according to the method of Deng et al. (2019) with slight modifications. The CPI/SPI $(0.2 \mathrm{~g})$ was mixed with $5 \mathrm{ml}$ of distilled water in a pre-weighed centrifuge tube. The mixture was vortexed for $2 \mathrm{~min}$ and then allowed to stand for $60 \mathrm{~min}$ at room temperature. The supernatant was carefully discarded after the dispersion was centrifuged at $8,000 \times \mathrm{g}$ for $20 \mathrm{~min}$. The total weight of the precipitate and the centrifuge tube was measured. The WHC was calculated according to the following equation:

$$
\mathrm{WHC}(\mathrm{g} / \mathrm{g})=\left(\mathrm{W}_{2}-\mathrm{W}_{1}\right) / \mathrm{W}_{0}
$$

Where:

$\mathrm{W}_{0}=$ The weight of protein isolate,

$\mathrm{W}_{1}=$ The weight of centrifuge tube and protein isolate sample, and

$\mathrm{W}_{2}=$ The weight of the centrifuge tube and precipitated protein isolate after absorbing water.

\section{Oil absorption capacity (OAC)}

For the determination of the oil absorption capacity of CPI/SPI, the method of Deng et al. (2019) was followed. CPI/SPI $(0.2 \mathrm{~g})$ was added to $5 \mathrm{ml}$ commercial corn oil in a pre-weighted centrifuge tube and then mixed for $2 \mathrm{~min}$ and allowed to stand for $60 \mathrm{~min}$ at room temperature. The mixture was centrifuged at $8,000 \times \mathrm{g}$ for $20 \mathrm{~min}$, and the supernatant was discarded. The OAC was calculated according to the following equation:

$$
\mathrm{OAC}(\mathrm{g} / \mathrm{g})=\left(\mathrm{W}_{2}-\mathrm{W}_{1}\right) / \mathrm{W}_{0}
$$

Where:

$\mathrm{W}_{0}=$ The weight of protein isolate,

$\mathrm{W}_{1}=$ The weight of centrifuge tube and protein isolate sample, and

$\mathrm{W}_{2}=$ The weight of the centrifuge tube and precipitated protein isolate after absorbing oil.

\section{Foaming properties}

The method described by Shahidi et al. (1995) and Elsohaimy et al. (2015) was used with some modification. CPI/SPI $(1 \mathrm{~g})$ was dispersed in distilled water, and the mixture was then adjusted to different $\mathrm{pH}$ values $(2$, $4,6,8,10)$. The dispersion was homogenized at $16,000 \mathrm{rpm}$ for $2 \mathrm{~min}$. The volume of the foam was recorded at 0 and $10 \mathrm{~min}$, respectively. Foam capacity (FC) was expressed as the percentage volume increase after homogenization, and foam stability (FS) was determined

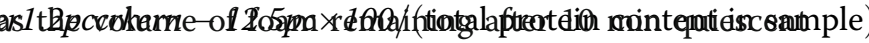
periods according to the following equation:

$$
\begin{aligned}
& \mathrm{FC}=\left(\mathrm{V}_{0}-\mathrm{V}\right) \times 100 / \mathrm{V} \\
& \mathrm{FS}=\left(\left(\mathrm{V}_{1}-\mathrm{V}\right) \times 100\right) /\left(\mathrm{V}_{0}-\mathrm{V}\right)
\end{aligned}
$$

Where: $\mathrm{V}(\mathrm{ml}), \mathrm{V}_{0}(\mathrm{ml}), \mathrm{V}_{1}(\mathrm{ml})$ are the volume of foam at initial, $0 \mathrm{~min}$, and $10 \mathrm{~min}$, respectively.

\section{Emulsifying properties}

The emulsifying activity index (EAI) was determined according to Hang et al. (2014) and Tontul et al. (2018) with slight modification. Briefly, CPI/SPI was dispersed in distilled water $(0.5 \% \mathrm{w} / \mathrm{v})$ and then adjusted to $\mathrm{pH} 7$ using $\mathrm{NaOH}$ or $\mathrm{HCl}(0.1$ or $1 \mathrm{M})$. Fifteen milliliters of the dispersion were then added to $5 \mathrm{ml}$ of corn oil and the mixture was blended using a high-speed homogenizer at $16,000 \mathrm{rpm}$ for $2 \mathrm{~min}$. After homogenization, $25 \mu \mathrm{l}$ of the emulsion were taken immediately and transferred to a tube, and diluted with $5 \mathrm{ml}$ SDS $(0.1 \%)$. The absorbance of the diluted emulsion was read at $500 \mathrm{~nm}$ using a spectrophotometer. The emulsion stability index (ESI) at $10 \mathrm{~min}$ was measured using the same procedure 
described. EAI and ESI were calculated using the following equation:

$$
\begin{aligned}
\operatorname{EAI}\left(\mathrm{m}^{2} / \mathrm{g}\right)= & \left(2 \times 2,303 \times \mathrm{A}_{0} \times \mathrm{DF}\right) /(\mathrm{C} \\
& \times \phi \times 10000) \\
\operatorname{ESI}(\mathrm{min})= & \mathrm{A}_{0} \times 10 /\left(\mathrm{A}_{0}-\mathrm{A}_{10}\right)
\end{aligned}
$$

where $A_{0}, A_{10}$ are the absorbance of the emulsion $0 \mathrm{~min}$, 10 min, respectively after emulsification, DF was the dilution factor, $\mathrm{C}$ was the concentration of the sample $(\mathrm{g} / \mathrm{ml}), \phi$ was the volume fraction of the oil in the emulsion.

\section{Statistical analysis}

All experiments were conducted in triplicates and data were reported as mean \pm standard deviation. One-way ANOVA was performed, and means were compared by using Tukey's HSD test $(p<0.05)$, SPSS 16.0 for Windows (SPSS Inc., Chicago, IL, USA).

\section{Results and discussion}

\section{SDS-PAGE profile of protein extract}

Two types of seed storage proteins are abundant in Brassicaceae oilseeds: legumin-type globulins (12 S or cruciferin) and napin-type albumins (2 $\mathrm{S}$ or napin). They account for 60 and $20 \%$ of the total proteins in mature seeds, respectively (Wanasundara 2011). Figure 1 indicates the electrophoretic protein profiles obtained from the meal of camelina and sophia meal. In camelina and sophia protein isolates (AE \& UAE), there were two major bands: $15-25 \mathrm{kDa}$ and $25-35 \mathrm{kDa}$. These bands refer to napin and cruciferin, respectively (Tan et al. 2011; Wanasundara 2011). The profile of camelina protein isolates is similar to those observed by Boyle et al. Boyle et al. (2018).

The protein band patterns for alkaline extraction (AE) and ultrasonic-assisted extraction (UAE) proteins were similar. Therefore, these gels showed that the primary structure of the protein in CPI and SPI has not been altered by ultrasonic-assisted extraction. similar results were recently observed in the ultrasonic-assisted extraction of proteins from chickpea, kidney bean, and soybean (Byanju et al. 2020).

\section{Surface hydrophobicity}

Surface hydrophobicity (SH) is an important characteristic that influences protein functionality. Higher surface hydrophobicity means that protein isolates have stronger surfactant properties (Mune and Sogi 2015; Tontul et al. 2018). It was found that the extract methods had different effects on the hydrophobicity surface of protein isolates from camelina and sophia seed meal. The $\mathrm{SH}$ of both camelina and sophia protein isolates prepared by $\mathrm{UAE}$ was significantly higher than that prepared by $\mathrm{AE}$ $(p<0.05)$. The highest $\mathrm{SH}$ for sophia protein isolates prepared by UAE was observed $(98.16 \mu \mathrm{g} \mathrm{BPB})$, and the lowest for soy protein isolates as a reference $(84.38 \mu \mathrm{g}$ $\mathrm{BPB}$ ) (Table 1). Significant differences in $\mathrm{SH}$ existed
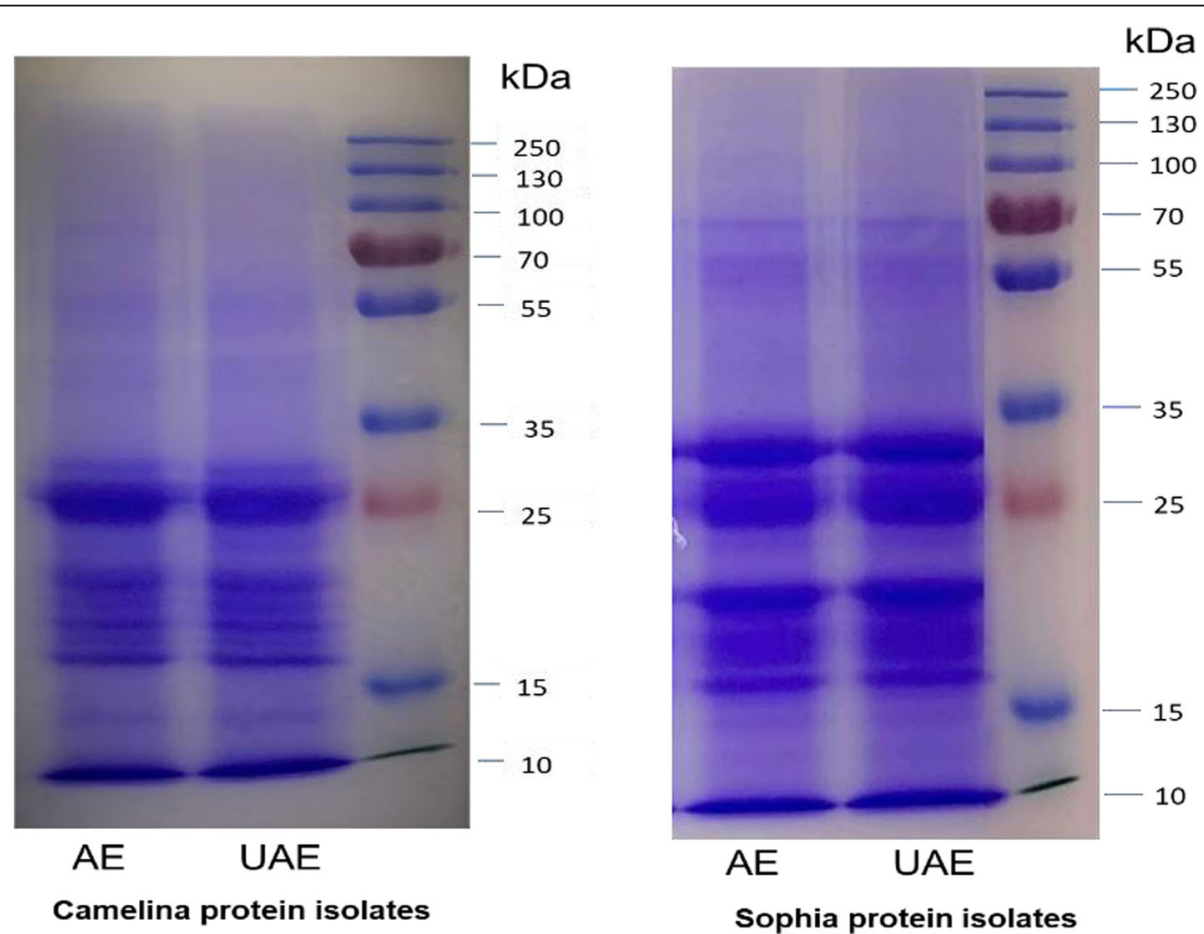

Fig. 1 SDS-PAGE profile of protein extract of camelina and sophia prepared using both the alkaline extraction (AE) and ultrasonic-assisted extraction (UAE) 
Table 1 Surface hydrophobicity ( $\mu$ g bound BPB) of camelina protein isolates (CPI) and sophia protein isolate (SPI)

\begin{tabular}{ll}
\hline & BPB bound $(\boldsymbol{\mu g})$ \\
\hline CPI (AE) & $90.39 \pm 0.40 \mathrm{c}$ \\
CPI (UAE) & $93.71 \pm 0.10 \mathrm{~b}$ \\
SPI (AE) & $93.15 \pm 0.40 \mathrm{~b}$ \\
SPI (UAE) & $98.16 \pm 0.45 \mathrm{a}$ \\
Soy PI & $84.38 \pm 0.65 \mathrm{~d}$
\end{tabular}

In the same column, means not connected by the same letter are significantly different at $p<0.05$

Values are presented as the mean \pm SD of each treatment in triplicate among extracted protein from different sources as reported (Mune and Sogi 2015; Tontul et al. 2018). Therefore, the variations in surface hydrophobicity of extracted protein could be due to changes in protein structure caused by ultrasound. It was reported the molecular structure of the protein is unfolded under ultrasound, thereby revealing the hydrophobic groups (Wang et al. 2020).

\section{Functional properties \\ Protein solubility}

Solubility is one of the most critical characteristics of protein isolates in food formulations as it relates to other functional properties, especially in foams, emulsions, and gels. It also influences the color, texture, and sensory quality of products (Deng et al. 2019; Tontul et al. 2018). According to Fig. 2, the protein solubility of CPI

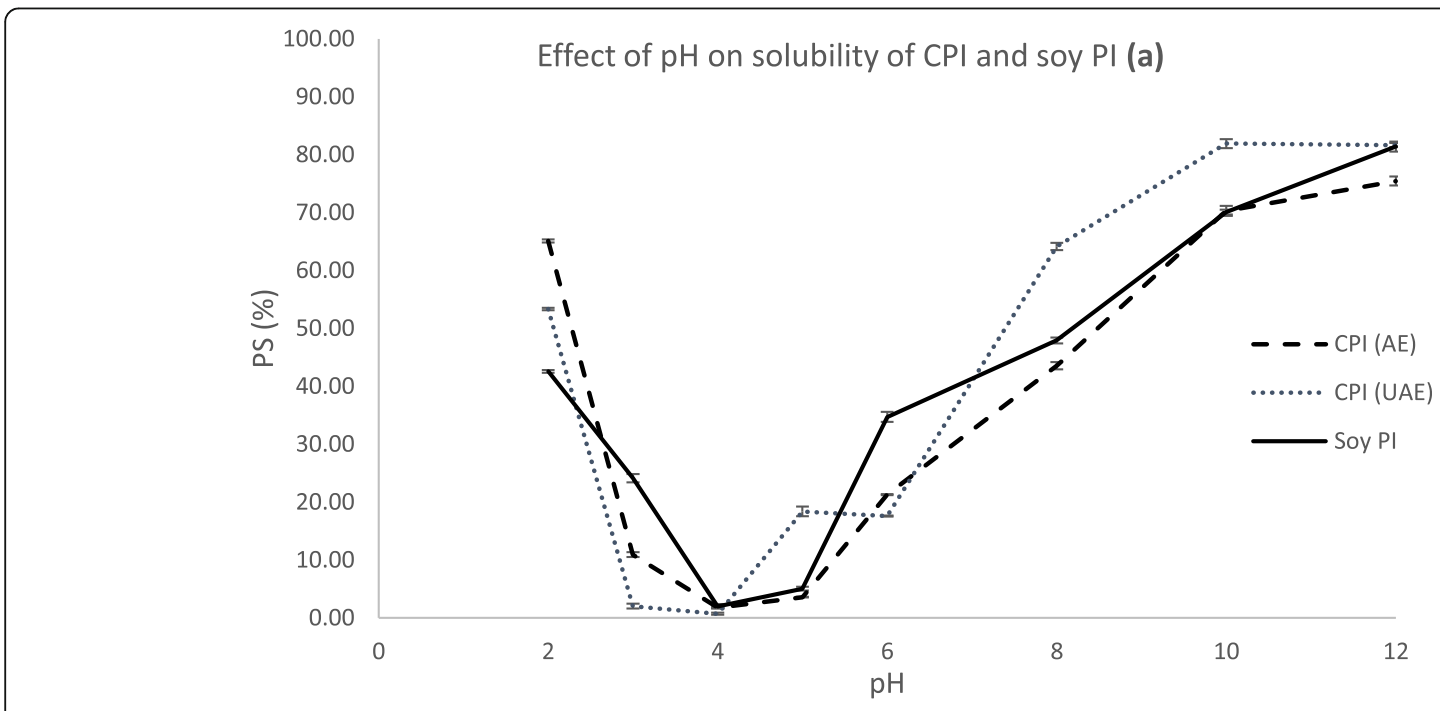

Effect of $\mathrm{pH}$ on SPI and Soy PI solubility (b)

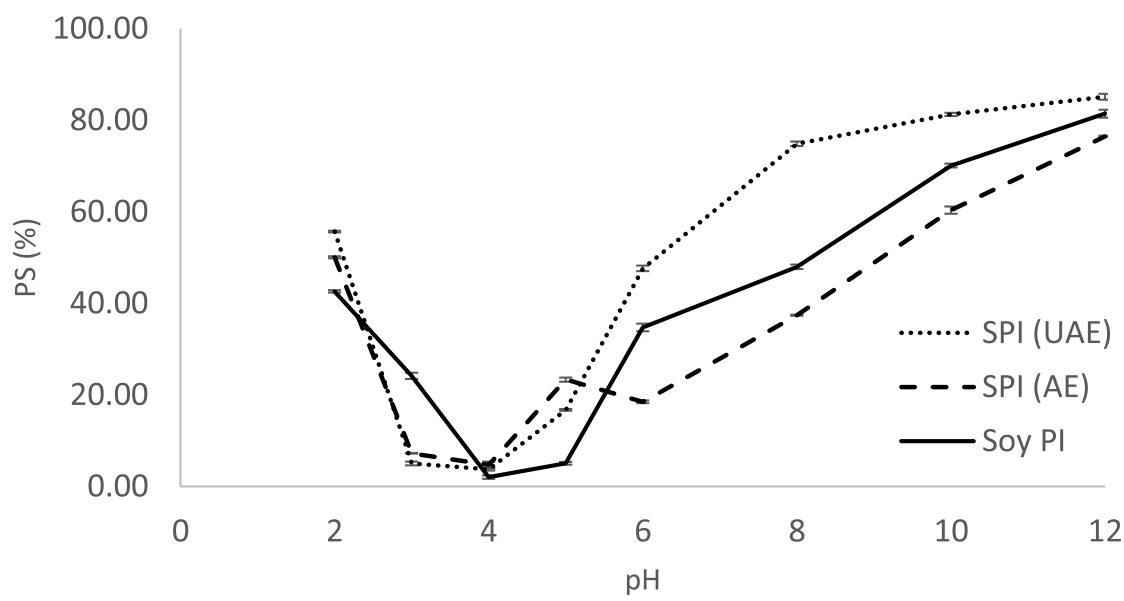

Fig. 2 (a \& b): Protein solubility (PS) of camelina and sophia obtained by alkali extraction (AE) and ultrasound-assisted alkali extraction (UAE) and soy protein isolate (Soy PI) as affected by $\mathrm{pH}$ 
Table 2 Water holding capacity (WHC) and oil absorption capacity $(\mathrm{OAC})$ of camelina protein isolate (CPI), sophia protein isolate (SPI) prepared by alkaline extraction (AE), and ultrasoundassisted alkali extraction (UAE) and Soy protein isolate (Soy PI)

\begin{tabular}{lll}
\hline & \multicolumn{2}{l}{ Functional properties } \\
\cline { 2 - 3 } & WHC $(\mathbf{g} / \mathbf{g})$ & OAC $(\mathbf{g} / \mathbf{g})$ \\
\hline CPI (AE) & $5.62 \pm 0.16 \mathrm{c}$ & $8.06 \pm 0.19 \mathrm{~d}$ \\
CPI (UAE) & $6.76 \pm 0.25 \mathrm{a}$ & $10.44 \pm 0.05 \mathrm{~b}$ \\
SPI (AE) & $6.32 \pm 0.17 \mathrm{ab}$ & $9.91 \pm 0.23 \mathrm{c}$ \\
SPI (UAE) & $6.04 \pm 0.12 \mathrm{bc}$ & $11.59 \pm 0.27 \mathrm{a}$ \\
Soy PI & $4.39 \pm 0.16 \mathrm{~d}$ & $5.28 \pm 0.12 \mathrm{e}$ \\
\hline
\end{tabular}

Values are presented as the mean \pm SD of each treatment in triplicate In the same column, means not connected by the same letter are significantly different at $P<0.05$

and SPI shows a typical U-shaped curve within the controlled $\mathrm{pH}$ range of 2-12. The PS of the samples were significantly affected by $\mathrm{pH}$ and indicated a minimum solubility near $\mathrm{pH} 3-5$, the isoelectric point region for these products. The low PS near the isoelectric point is due to the balance of positive and negative charges which reduces the electrostatic repulsion among the protein molecules and leads to aggregation and precipitation. In addition, the PS of samples increased gradually with the increase in $\mathrm{pH}$ (5-12), and CPI was most soluble at $\mathrm{pH} 12$. These results also correspond to previous studies on different sample types such as rapeseed protein (Dong et al. 2011), quinoa protein isolate (Elsohaimy et al. 2015), mung bean protein ( $\mathrm{Du}$ et al. 2018), chickpea protein isolate (Tontul et al. 2018), and Chinese quince seed protein isolate (Deng et al. 2019).

Figure $2(\mathrm{a} \& \mathrm{~b})$ also shows that the PS of soy PI was higher than both CPI (AE) and SPI (AE), however, it was lower than that of UAE. Thus, the solubility of UAE protein isolates improved significantly compared with $\mathrm{AE}$ at the $\mathrm{pH}$ range of 6-12. Many factors, including the molecular size and composition of protein, influence protein solubility. The decreased particle size caused by ultrasound is likely to increase protein solubility due to better interaction between protein and water (Wang et al. 2020; Yu et al. 2019; Zhang et al. 2018).

\section{Water holding capacity and oil absorption capacity}

Water holding capacity is a measure of the ability of proteins to associate gravity with water and it is closely associated with food products' texture, mouthfeel, and viscosity (Deng et al. 2019). The WHC of CPI and SPI is significantly higher than that of soy PI (Table 2) $(p<$ 0.05). Besides, the WHC of CPI (UAE) increased by $20.3 \%$ compared with that of CPI (AE) while the WHC of SPI prepared UAE was significantly unchanged. This can be explained by the decrease of the particle size and the improvement of protein solubility for samples extracted by UAE (Wang et al. 2020). Therefore, CPI and SPI could be used to possibly replace soy protein isolates in certain foods.

In general, the oil absorption capacity of proteins represents their ability to bind to oil. It is closely correlated with flavor retention, shelf life, and emulsifying properties. This characteristic may be influenced by factors such as amino acid composition, the type of oil employed, and hydrophobicity, as well as the method used to extract the protein (Deng et al. 2019; Dong et al. 2011). The results in Table 2 show that the oil adsorption ability of CPI and SPI was better than that of soy PI. Compared with AE, the OAC of CPI (UAE) and SPI (UAE) were more enhanced by $29.52 \%$ and $16.95 \%$,

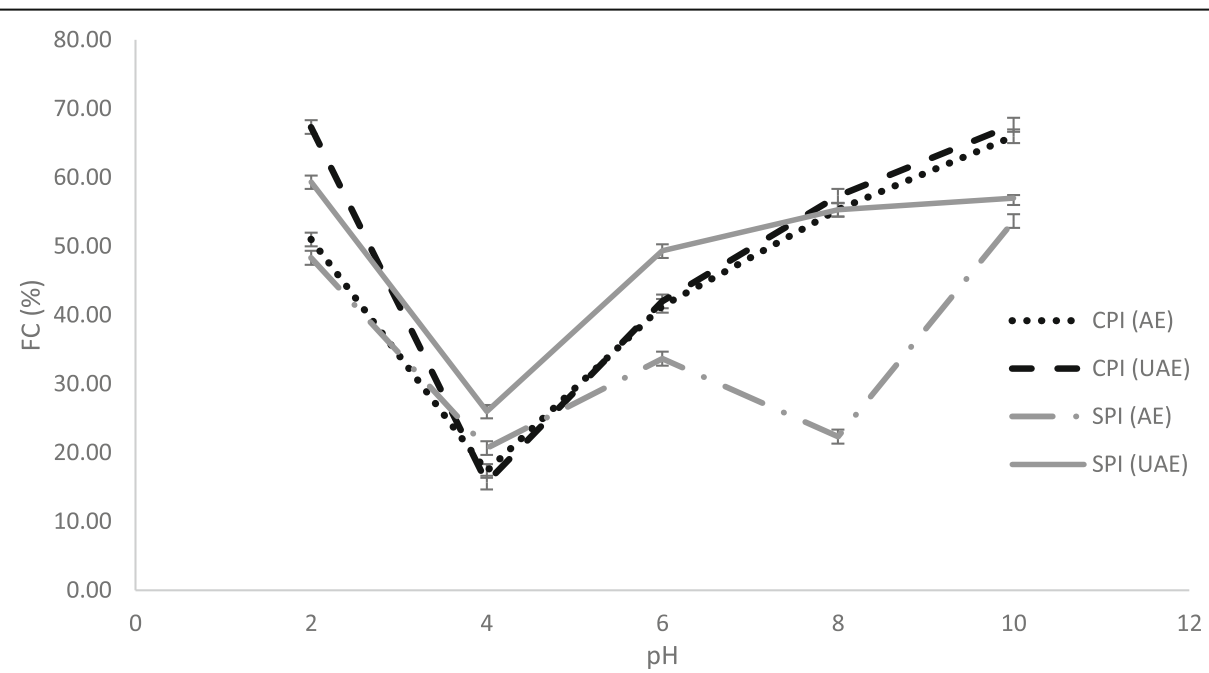

Fig. 3 Effect of pH on foaming capacity (FC) of camelina protein isolate (CPI) and sophia protein isolate (SPI) prepared by alkaline extraction (AE) and ultrasound-assisted alkali extraction (UAE) 


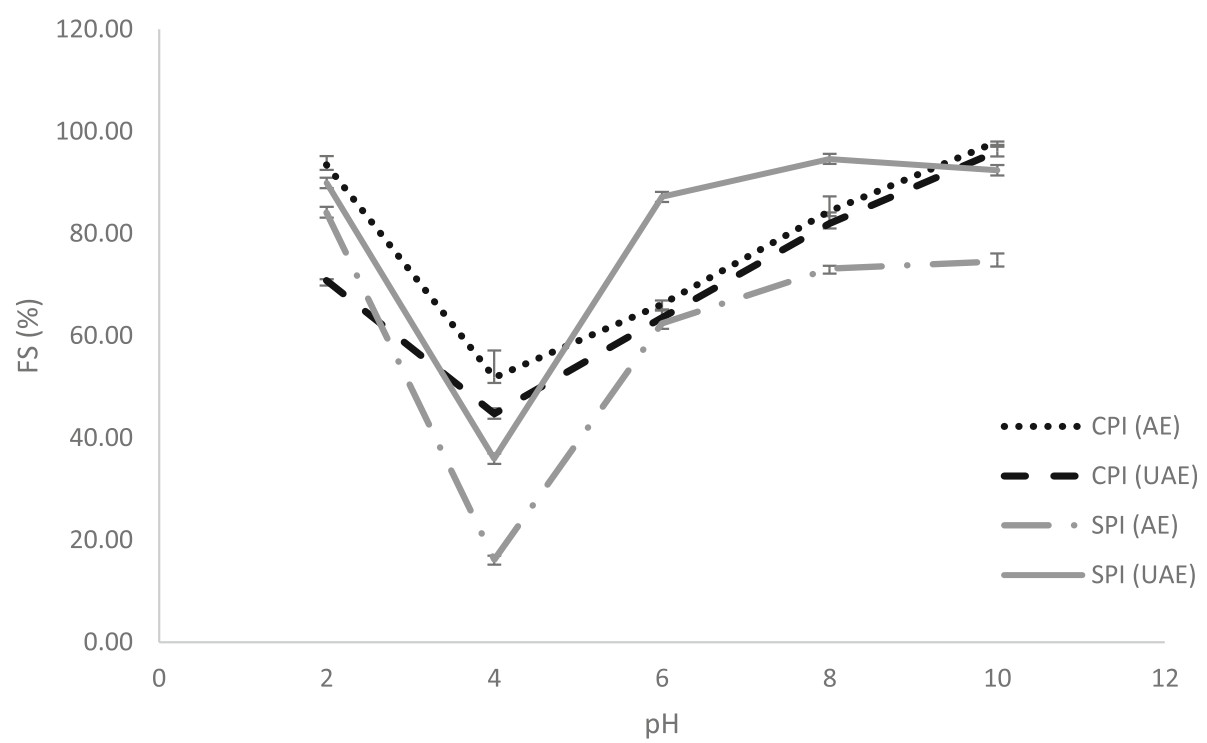

Fig. 4 Effect of pH on foam stability (FS) of camelina protein isolate (CPI) and sophia protein isolate (SPI) prepared by alkaline extraction (AE) and ultrasound-assisted alkali extraction (UAE)

respectively. The improved OAC could be due to the exposure of hydrophobic groups after using UAE. The surface hydrophobicity of CPI and SPI using UAE increased in this analysis, which may make up for the increased $\mathrm{OAC}$ of protein isolates.

\section{Foaming properties}

Foaming properties are correlated with the ability to decrease surface tension at the water-air interface and are strongly linked to the protein structure. Also, the foam capacity and foam stability are strongly correlated with protein solubility. The higher protein solubility improves water-protein interactions and helps to unfold the protein structure, therefore enhancing air encapsulation (Mundi and Aluko 2012; Zhang et al. 2018). As shown in Figs. 3 and 4, the lowest FC and FS in all samples was at $\mathrm{pH} 4$ which is the point of least protein solubility. It may be because the ability of proteins to diffuse to form bubbles in the water/air interface is limited. However, it tends to decrease from $\mathrm{pH} 2$ to $\mathrm{pH} 3$ and increase in the $\mathrm{pH}$ 5-10 range. The results correspond with the reported protein solubility within the $\mathrm{pH} 2-10$ range. With UAE, the FC and FS of SPI were significantly higher than that of $\mathrm{AE}$ while they were relatively

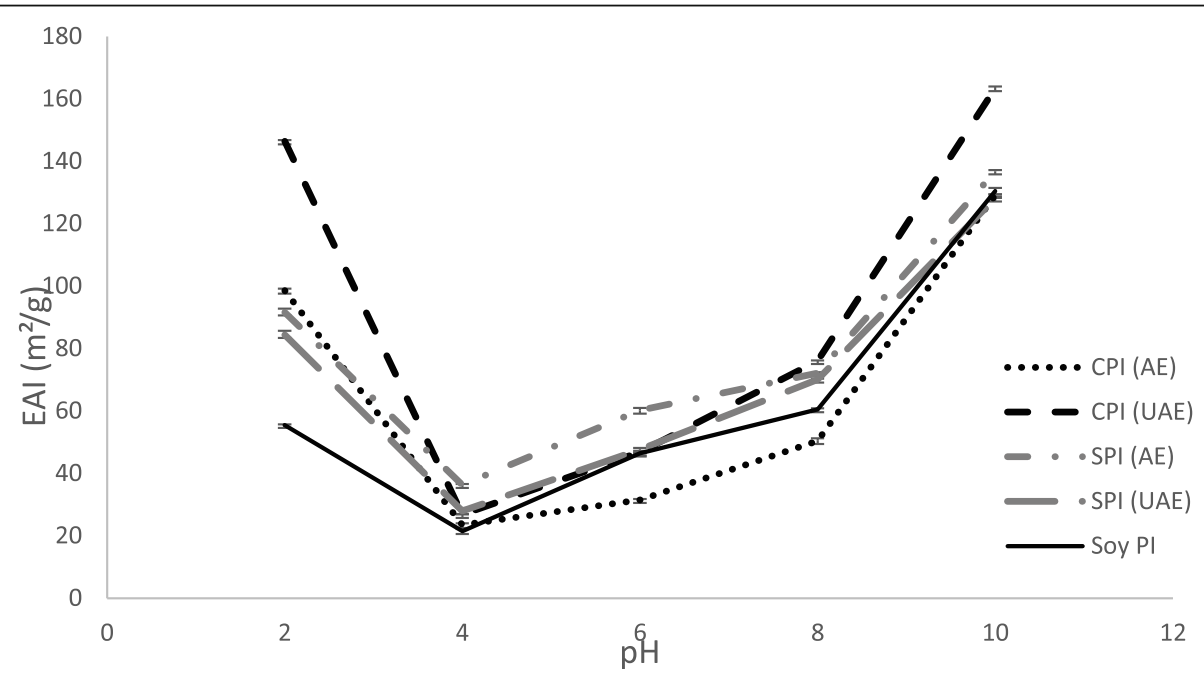

Fig. 5 Effect of pH on emulsifying ability index (EAI) of camelina protein isolate (CPI) and sophia protein isolate (SPI) prepared by alkaline extraction (AE) and ultrasound-assisted alkali extraction (UAE) 


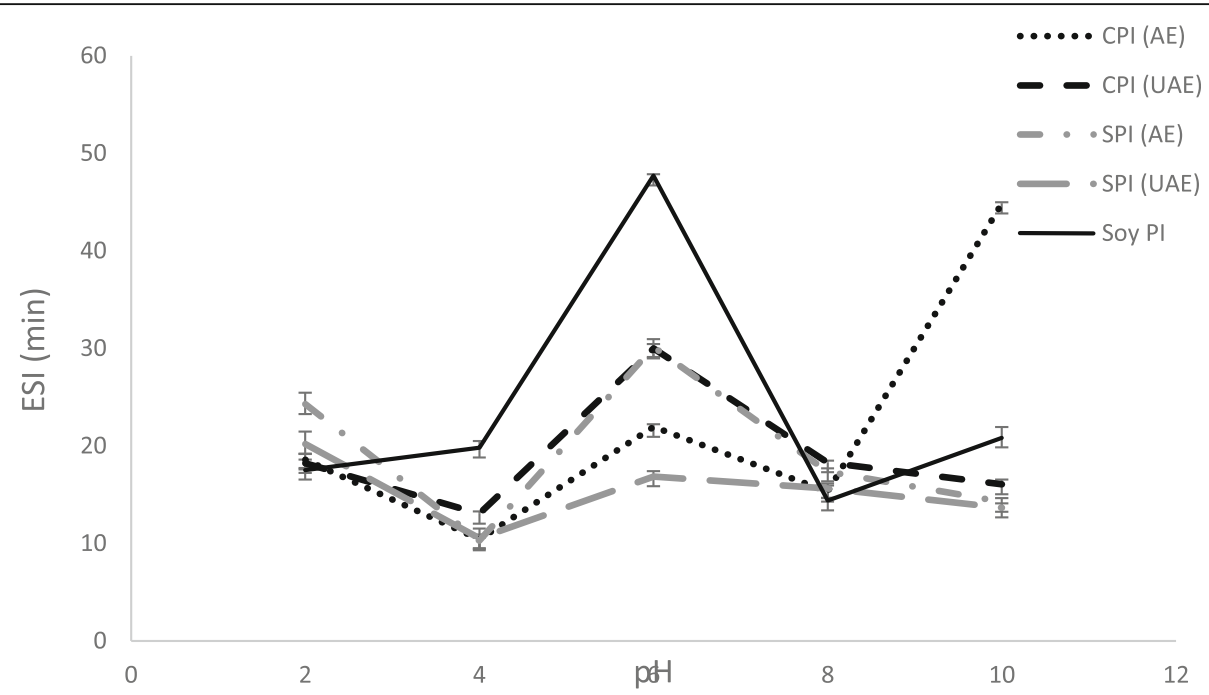

Fig. 6 Effect of pH on emulsifying stability index (ESI) camelina protein isolate (CPI) and sophia protein isolate (SPI) prepared by alkaline extraction (AE) and ultrasound-assisted alkali extraction

unchanged in CPI. Ultrasound-assisted alkali extraction could increase foam formation causing changes in protein structure and increase surface hydrophobicity (Wang et al. 2020).

\section{Emulsifying properties}

The emulsifying ability index (EAI) and emulsion stability index (ESI) of CPI at various $\mathrm{pH}$ were observed as shown in Figs. 5 and 6, using soybean protein isolate (soy PI) as a reference. The EAI of all samples showed U shape curves within the $\mathrm{pH} 2-10$ range related to the relationship between protein solubility and $\mathrm{pH}$. Figure 5 shows that the lowest EAI was at $\mathrm{pH} 4$, close to the isoelectric point. Besides, the EAI of all samples decreased rapidly when the $\mathrm{pH}$ increased from 2 to 4 , while there was a sequential increase of EAI within the $\mathrm{pH} 6-10$ range and reached the highest value at $\mathrm{pH} 10$. The results were similar to those reported for canola/rapeseed (Dong et al. 2011; Tan et al. 2011). The EAI of CPI (UAE) was significantly higher than that of CPI (AE), while the trend of EAI in both SPI (UAE) and SPI(AE) was similar and remained unchanged. The ultrasoundassisted extraction method affects the structure of protein isolates by enhancing molecular flexibility and surface hydrophobicity (Wang et al. 2020). Figure 6 shows the lowest of ESI at $\mathrm{pH} \mathrm{4,} \mathrm{near} \mathrm{the} \mathrm{isoelectric}$ point, while the highest was at $\mathrm{pH} 6$. The low ESI could be due to the poor solubility, unsatisfactory hydration, and weak electrostatic repulsion among the protein molecules that were insufficiently strong to prevent oil droplet aggregation. Moreover, the EAI of all samples was higher than that of soy PI at most tested $\mathrm{pH}$ values, except CPI (AE) for $\mathrm{pH}$ 6-10. This suggests the CPI and SPI prepared by UAE emulsifying ability, making it a good candidate emulsifying agent for use in the food industry.

\section{Conclusions}

The ultrasonic-assisted extraction method was more effective than the traditional method for the extraction of proteins from camelina and sophia seed meals. There were no differences in protein subunit bands for all the samples prepared by ultrasonic-assisted extraction. The surface hydrophobicity of CPI and SPI was higher than that of soybean protein isolates. Ultrasonic-assisted extraction significantly improved water holding capacity and oil absorption capacity, emulsifying capacity, and foaming capacity of the CPI and SPI which indicate the potential use of CPI and SPI as a replacement for soybean protein in food formulations. Further studies on the protein value and digestibility of CPI and SPI are necessary for their application as food ingredients.

\section{Abbreviations}

CPI: Camelina protein isolate; SPI: Sophia protein isolate; Soy PI: Soy protein isolate; SDS-PAGE: Sodium dodecyl sulfate-polyacrylamide gel electrophoresis; AE: Alkaline extraction; UAE: Ultrasonic-assisted extraction; BPB: Bromophenol blue; SH: Surface hydrophobicity; PS: Protein solubility; WHC: Water holding capacity; OAC: Oil absorption capacity; FC: Foaming capacity; FS: Foam stability; EAI: Emulsifying activity index; ESI: Emulsion stability index

\section{Acknowledgements}

We are grateful to the Natural Science and Engineering Research Council (NSERC) of Canada for financial support. Ngo thanks support from Vietnam International Education Development for a scholarship.

\section{Authors' contributions}

Dr. Shahidi F proposed and supervised the project while Na T.T.N. conducted the experiments and analyzed data. Authors Na T.T.N. drafted the manuscript while Dr. Shahidi F reviewed, revised and edited the manuscript. The final document was read and approved by the author(s). 


\section{Availability of data and materials}

Please contact Dr. Fereidoon Shahidi for data requests.

\section{Declarations}

\section{Competing interests}

Dr. Fereidoon Shahidi is editor-in-chief of Food Production, Processing and Nutrition and he was not involved in the journal's review of, or decisions related to this manuscript.

Received: 25 June 2021 Accepted: 20 September 2021

Published online: 26 October 2021

\section{References}

Berot, S., Compoint, J. P., Larre, C., Malabat, C., \& Gueguen, J. (2005). Large scale purification of rapeseed proteins (Brassica napus L.). Journal of Chromatography B, 818(1), 35-42. doi:https://doi.org/10.1016/j.jchromb.2004. 08.001

Boyle, C., Hansen, L., Hinnenkamp, C., \& Ismail, B. P. (2018). Emerging Camelina Protein: Extraction, Modification, and Structural/Functional Characterization. Journal of the American Oil Chemists' Society, 95(8), 1049-1062. doi:https://doi. org/10.1002/aocs.12045

Byanju, B., Rahman, M. M., Hojilla-Evangelista, M. P., \& Lamsal, B. P. (2020). Effect of high-power sonication pretreatment on extraction and some physicochemical properties of proteins from chickpea, kidney bean, and soybean. International Journal of Biological Macromolecules, 145, 712-721. doi: https://doi.org/10.1016/j.ijbiomac.2019.12.118

Das, N., Berhow, M. A., Angelino, D., \& Jeffery, E. H. (2014). Camelina sativa defatted seed meal contains both alkyl sulfinyl glucosinolates and quercetin that synergize bioactivity. Journal of Agricultural and Food Chemistry, 62(33), 8385-8391. doi:https://doi.org/10.1021/jf501742h

Deng, Y., Huang, L., Zhang, C., Xie, P., Cheng, J., Wang, X., \& Li, S. (2019). Physicochemical and functional properties of Chinese quince seed protein isolate. Food Chemistry, 283, 539-548. doi:https://doi.org/10.1016/j. foodchem.2019.01.083

Dong, X. Y., Guo, L. L., Wei, F., Li, J. F., Jiang, M. L., Li, G. M., \& Chen, H. (2011). Some characteristics and functional properties of rapeseed protein prepared by ultrasonication, ultrafiltration and isoelectric precipitation. Journal of the Science of Food and Agriculture, 91(8), 1488-1498. doi:https://doi.org/10.1002/ jsfa.4339

Du, M., Xie, J., Gong, B., Xu, X., Tang, W., Li, X., \& Xie, M. (2018). Extraction, physicochemical characteristics and functional properties of Mung bean protein. Food Hydrocolloids, 76, 131-140. doi:https://doi.org/10.1016/j. foodhyd.2017.01.003

Elsohaimy, S. A., Refaay, T. M., \& Zaytoun, M. A. M. (2015). Physicochemical and functional properties of quinoa protein isolate. Annals of Agricultural Sciences, 60(2), 297-305. doi:https://doi.org/10.1016/j.aoas.2015.10.007

Flores-Jimenez, N. T., Ulloa, J. A., Silvas, J. E. U., Ramirez, J. C. R., Ulloa, P. R., Rosales, P. U. B., \& Leyva, R. G. (2019). Effect of high-intensity ultrasound on the compositional, physicochemical, biochemical, functional and structural properties of canola (Brassica napus L.) protein isolate. Food Research International, 121, 947-956. doi:https://doi.org/10.1016/j.foodres.2019.01.025

HadiNezhad, M., Rowland, O., \& Hosseinian, F. (2015). The Fatty Acid Profile and Phenolic Composition of Descurainia sophia Seeds Extracted by Supercritical CO2. Journal of the American Oil Chemists' Society, 92(9), 1379-1390. doi: https://doi.org/10.1007/s11746-015-2693-5

Li, N., Qi, G., Sun, X. S., Wang, D., Bean, S., \& Blackwell, D. (2014). Isolation and Characterization of Protein Fractions Isolated from Camelina Meal. American Society of Agricultural and Biological Engineers, 57, 169-178. doi:https://doi. org/10.13031/trans.57.10455

Li, N., Qi, G., Sun, X. S., Xu, F., \& Wang, D. (2015). Adhesion properties of camelina protein fractions isolated with different methods. Industrial Crops and Products, 69, 263-272. doi:https://doi.org/10.1016/j.indcrop.2015.02.033

Ly, H. L., Tran, T. M. C., Tran, T. T. T., Ton, N. M. N., \& Le, V. V. M. (2018). Application of ultrasound to protein extraction from defatted rice bran. International Food Research Journal, 25(2), 695-701

Malik, M. A., \& Saini, C. S. (2018). Rheological and structural properties of protein isolates extracted from dephenolized sunflower meal: Effect of high intensity ultrasound. Food Hydrocolloids, 81, 229-241. doi:https://doi.org/10.1016/j. foodhyd.2018.02.052
Malik, M. A., Sharma, H. K., \& Saini, C. S. (2017). High intensity ultrasound treatment of protein isolate extracted from dephenolized sunflower meal: Effect on physicochemical and functional properties. Ultrasonics Sonochemistry, 39, 511-519. doi:https://doi.org/10.1016/j.ultsonch.2017.05.026

Martinez-Velasco, A., Lobato-Calleros, C., Hernandez-Rodriguez, B. E., RomanGuerrero, A., Alvarez-Ramirez, J., \& Vernon-Carter, E. J. (2018). High intensity ultrasound treatment of faba bean (Vicia faba L.) protein: Effect on surface properties, foaming ability and structural changes. Ultrasonics Sonochemistry, 44, 97-105. doi:https://doi.org/10.1016/j.ultsonch.2018.02.007

Mohamed, N. H., \& Mahrous, A. E. (2009). Chemical Constituents of Descurainia sophia L. and its Biological Activity.Academy of Chemistry of Globe Publications,58-67.

Mundi, S., \& Aluko, R. E. (2012). Physicochemical and functional properties of kidney bean albumin and globulin protein fractions. Food Research International, 48(1), 299-306. doi:https://doi.org/10.1016/j.foodres.2012.04.006

Mune, M. A. M., \& Sogi, D. S. (2015). Emulsifying and Foaming Properties of Protein Concentrates Prepared from Cowpea and Bambara Bean Using Different Drying Methods. International Journal of Food Properties, 19(2), 371384. doi:https://doi.org/10.1080/10942912.2015.1023399

Pastuszewska, B., Jabøecki, G., SÂwie, E., Buraczewska, L., \& OchtabinÂska, A. (2000). Nutritional value of rapeseed meal containing lecithin gums precipitated with citric acid. Animal Feed Science and Technology, 86, 117-123

Phongthai, S., Lim, S. T., \& Rawdkuen, S. (2016). Optimization of microwaveassisted extraction of rice bran protein and its hydrolysates properties. Journal of Cereal Science, 70, 146-154. doi:https://doi.org/10.1016/j.jcs.201 6.06 .001

Rahman, M. J., Ambigaipalan, P., \& Shahidi, F. (2018a). Biological Activities of Camelina and Sophia Seeds Phenolics: Inhibition of LDL Oxidation, DNA Damage, and Pancreatic Lipase and alpha-Glucosidase Activities. Journal of Food Science, 83(1), 237-245. doi:10.1111/1750-3841.14007

Rahman, M. J., Costa de Camargo, A. \& Shahidi, F. (2018b). Phenolic profiles and antioxidant activity of defatted camelina and sophia seeds. Food Chemistry, 240, 917-925. doi:10.1016/j.foodchem.2017.07.098

Tan, S. H., Mailer, R. J., Blanchard, C. L., \& Agboola, S. O. (2011). Canola proteins for human consumption: extraction, profile, and functional properties. Journal of Food Science, 76(1), R16-28. doi:https://doi.org/1 0.1111/j.1750-3841.2010.01930.x

Tontul, I., Kasimoglu, Z., Asik, S., Atbakan, T., \& Topuz, A. (2018). Functional properties of chickpea protein isolates dried by refractance window drying. International Journal of Biological Macromolecules, 109, 1253-1259. doi:https:// doi.org/10.1016/j.jjbiomac.2017.11.135

Wanasundara, J. P. (2011). Proteins of Brassicaceae oilseeds and their potential as a plant protein source. Critical Reviews in Food Science and Nutrition, 51(7), 635-677. doi:https://doi.org/10.1080/10408391003749942

Wang, F., Zhang, Y., Xu, L., \& Ma, H. (2020). An efficient ultrasound-assisted extraction method of pea protein and its effect on protein functional properties and biological activities. LWT - Food Science and Technology. 127, doi:https://doi.org/10.1016/i.lwt.2020.109348

Yagoub, A. A., Ma, H., \& Zhou, C. (2017). Ultrasonic-assisted extraction of protein from rapeseed (Brassica napus L.) meal: Optimization of extraction conditions and structural characteristics of the protein. International Food research Jounal, 24(2), 621-629

Yu, C., Wu, F., Cha, Y., Zou, H., Guo, Y., Piao, H., \& Du, M. (2019). Structural and Functional Changes in Ultrasonicated Oyster Protein Isolates. International Journal of Food Engineering\&nbsp;15 (3-4), doi:https://doi.org/10.1515/ife-2018-0190

Zhang, L., Pan, Z., Shen, K., Cai, X., Zheng, B., \& Miao, S. (2018). Influence of ultrasound-assisted alkali treatment on the structural properties and functionalities of rice protein. Journal of Cereal Science, 79, 204-209. doi: https://doi.org/10.1016/j.jcs.2017.10.013

Zhu, Z., Zhu, W., Yi, J., Liu, N., Cao, Y., Lu, J., \& McClements, D. J. (2018). Effects of sonication on the physicochemical and functional properties of walnut protein isolate. Food Research International, 106, 853-861. doi:https://doi. org/10.1016/j.foodres.2018.01.060

Zou, Y., Wang, L., Li, P., Cai, P., Zhang, M., Sun, Z., \& Wang, D. (2017). Effects of ultrasound assisted extraction on the physiochemical, structural and functional characteristics of duck liver protein isolate. Process Biochemistry, 52, 174-182. doi:https://doi.org/10.1016/j.procbio.2016.09.027

\section{Publisher's Note}

Springer Nature remains neutral with regard to jurisdictional claims in published maps and institutional affiliations. 